\title{
CARACTERIZACIÓN FÍSICO-QUÍMICA DE UNA ARCILLA COLOMBIANA
}

\section{PHYSICOCHEMICAL CHARACTERIZATION OF A COLOMBIAN CLAY}

\author{
MSc. Ricardo Andrés García-León*,**, MSc. Eder Flórez Solano* \\ MSc. Wilder, Quintero-Quintero** \\ *Universidad Francisco de Paula Santander Ocaña, \\ Facultad de Ingenierías, Grupo de Investigación INGAP. \\ Vía Acolsure, Sede el Algodonal - Ocaña, Norte de Santander, Colombia. \\ Tel.: +57 5690088 Ext. 191. \\ E-mail: (ragarcial, enflorezs, quinterow) @ufpso.edu.co. \\ ${ }^{* *}$ Instituto Politécnico Nacional, Grupo Ingeniería de Superficies, \\ SEPI-ESIME, U.P. Adolfo López Mateos, Zacatenco, \\ Ciudad de México 07738, México,
}

Resumen: Las arcillas son de gran importancia a nivel industrial debido a que pueden usarse para fabricar productos de mampostería como bloques, azulejos, ladrillos, azulejos, entre otros; Actualmente, muchas empresas del sector cerámico obtienen gran cantidad de residuos debido a la falta de análisis tecnológicos de la materia prima que permitan pronosticar el comportamiento de las mezclas cerámicas y mejorar la calidad del producto final. En el presente trabajo, se realizó la caracterización física y química de la arcilla utilizada en una de las empresas dedicadas a la fabricación de productos de mampostería para la construcción en Ocaña, Norte de Santander-Colombia. El desarrollo de la investigación se llevó a cabo mediante caracterización de la materia prima seleccionada de diferentes puntos de la cantera de la empresa, con la que se determinó la granulometría, índice de plasticidad y la composición mineralógica. Los resultados obtenidos muestran que las arcillas actualmente utilizadas por la empresa se encuentran en un nivel bajo para la fabricación de productos de mampostería; para mejorar la calidad de la mezcla de arcilla se propone la adición de otras arcillas, con lo que se logra una mezcla óptima con la que se pueden cumplir los requisitos de la normativa vigente.

Palabras clave: Arcilla, mampostería, hidrometría, tamizado, DRX, FXR.

Abstract: Clays are of great importance at the industrial level because can be used to manufacture masonry products such as blocks, tiles, bricks, tiles, among others; Currently, many companies in the ceramic sector obtain a large amount of waste due to the lack of technical analysis of the raw material that allows predicting the behavior of ceramic mixtures and improving the quality of the final product. In the present work, the physical and chemical characterization of the clay used in one of the companies dedicated to the manufacture of masonry products for construction in Ocaña, Norte de Santander-Colombia, was made. The development of the 
research was carried out by characterizing the selected raw material from different points in the company's quarry, with which the granulometry, plasticity index, and mineralogical composition were determined. The results obtained show that the clays currently used by the company have a low level for the manufacture of masonry products. A proposed is to improve the quality of the clay mix, which is the addition of other clays, which achieves an optimal mix with which the requirements of current regulations can be met.

Keywords: Clay, Masonry, Hydrometry, Sieving, XRD, XRF.

\section{INTRODUCTION}

Colombia is not a high power in industrial manufacturing of products based on clay, regardless of whether it is a great abundance of this optimal raw material in the soil. The ceramic sector in the Norte de Santander area is widely used, being recognized not only nationally, but also internationally. However, in the ceramics companies of the region, there is a profound ignorance of the characteristics and behavior of the raw materials used in the manufacture of products derived from clay (Gelves \& Sánchez, 2009); (L Tangarife et al., 2017).

Due to a great variety of natural deposits in the region whose export of materials made of clay does not exceed $5.7 \%$ of total exports at the regional level, representing approximately 13.7 million dollars for the economy of the department as of July 2013; and taking into account that these values about construction materials are only reflected for the municipality of Cucuta and its metropolitan area, the only municipality that has SMEs in terms of manufacturing clay materials (Martínez \& Aguilar, 2012) (Montoya \& Montoya, 2014); (J Plaza, M Núñez, 2017).

The clay transformation process is mainly composed of three phases, which are; preparation of ceramic paste, molding of the piece, and cooking. The preparation process is the first phase, where the composition and plasticity are modified by adding other clays from the region in order to obtain a homogeneous ceramic paste; in the second molding phase, the desired shape must be taken into account if will lead to pressure or extrusion. Once the molded part has been obtained, the last phase is dried, where the evaporation rate of water is controlled in order to avoid defects in the piece. Subsequently, the piece is sintered, it is subjected to the baking process in order to reduce porosity, increase density and mechanical strength (Muñoz, Muñoz, Mancilla, \& Rodríguez, 2007) (Barranzuela, 2014) (Jácome Manzano, 2012) (R.A. García-León \& Flórez, 2016) (R.A. García-León, Bolívar, \& Flórez, 2016). The physical, chemical, and mineralogical characteristics of clays vary widely, even between the layers of the same clay deposit. Therefore, in any ceramic industry, the quality control of the products begins with the characterization and quality control of its clays. Clays are generally used in the manufacture of construction products, with an equivalent of $90 \%$, the remaining $10 \%$ have other uses such as rubbers, paints, molding sands, agriculture, and paper, among other products (García \& Suárez, 2004). Mines that contain clay materials in their composition are classified depending on their mineralogy, chemical composition, geological origin, physical properties, industrial use, geotechnical behavior, among other classifications. However, the most common and the best known is the mineralogical classification, among others that can find, according to their molecular structure, clays of type kaolin, illite, and montmorillonite (Díaz \& Torrecillas, 2002); (O Suarez at el, 2018) According to the production capacity and technological development, brick industries have been classified as chircal, small, medium, and large bricks (Riojas Castillo \& Rodríguez Montaña, 2004). In general, these industries maintain the production process, as can be seen in Figure 1.

The process and the variables involved in each of its stages of the production process is essential to identify, such as the research conducted by (Ricardo Andrés García-León \& Flórez, 2016). As well as the characterization of the raw 
material (clay) by different methods such as physical, chemical and mechanical tests, in order to know the behavior in the different stages of production and how to validate the final product with quality conditions based on the current standards such as NTC 4017 and 4205 that govern masonry products for construction (García-León, Bolívar León, et al., 2016)( R.A. García-León \& Bolívar-León, R 2017).

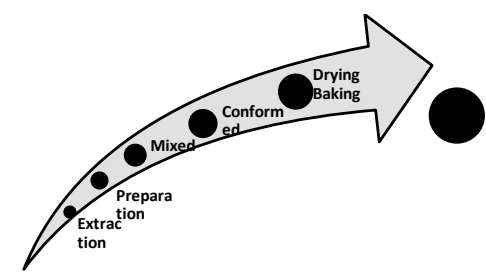

Figure 1. The production process of a brick.

Source. Own elaboration

Other studies analyzed a sample of red clay and determined its chemical composition and crystalline phases; Besides, the particle size distribution and thermal analysis was determined, the density and limits of Atterberg; where they subsequently evaluated the samples thermally at $1050{ }^{\circ} \mathrm{C}$, in addition to chemical analyses such as DRX and FRX (Zuluaga Castrillón et al., 2016) (Perales López \& Barrera Vargas, 2013)(Cely-Illera, 2016) (R.A. GarcíaLeón, Flórez-Solano, \& Acevedo-Peñaloza, 2018b)(R.A. García-León, Flórez-Solano, \& Medina-Cardenas, 2018). In this article shows a study through physical and chemical analysis (technological characterization) of the clays used by a company dedicated to the manufacture of masonry products for construction, where the raw material is analyzed in each of the stages of the process to validate their baking behavior through physical analysis with hydrometry tests and thus validate the results with chemical and mineralogical analysis with the help of the X-ray diffraction and fluorescence test.

\section{MATERIALS AND METHODS}

The clay samples were collected directly in the mines of the Ladrillera by direct observation. Likewise, from the results of the test that were obtained from the samples, the variables for the approach and implementation of the experimental studies were determined. In addition, laboratory tests were carried out in order to determine the variables that were the object of the study, to identify those have the greatest impact and thus design the optimal mixture in the manufacture of $\mathrm{H}-10$ blocks (R.A. García-León, Acosta, \& Flórez, 2015) (R.A. García-León \& Flórez, 2016)(R.A. García-León et al., 2016)( R.A. García-León \& Bolívar, 2017) (R.A. García-León, Flórez-Solano, \& Rodríguez-Castilla, 2019). Also, samples M1, M2, M3, M4, and M5 were selected from the different mines of the company. Figure 2 shown the detailed description of the different stages that are carried out in the clay for the manufacture of masonry products for the company under study:

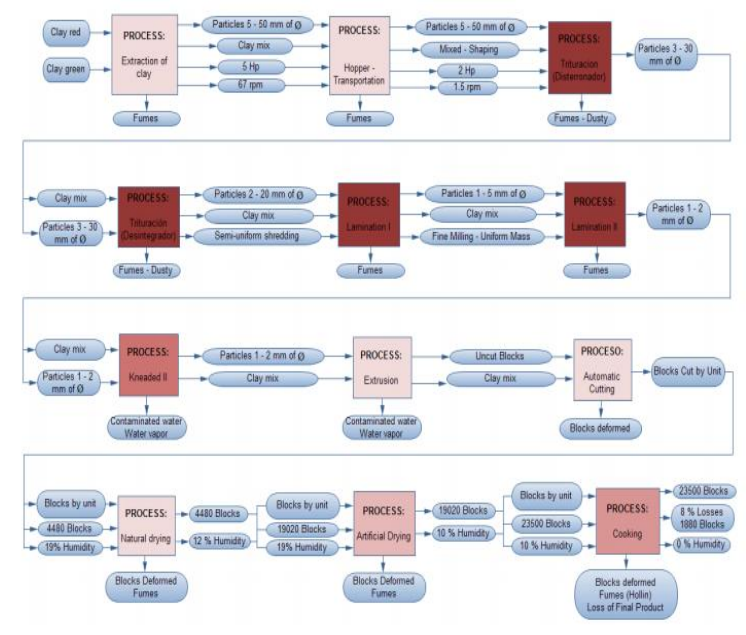

Figure 2. Description of the process stages. Source: (R.A. García-León, Acevedo-Peñaloza, \& Rojas-Suarez, 2019)(R.A. García-León, Flórez-Solano, \& Acevedo-Peñaloza, 2018).

The clays can be classified according to Mineralography (rich in kaolinite), chemistry (high alumina content), geological origin (sedimentary type), physical properties (plasticity index), industrial use (refractory sector, construction, among others), among other parameters. Based on the mineralogy, which is one of the main ways of classifying them, the clays are contained in clay minerals and non-clay minerals, which are what provide the plasticity and drying and cooking properties of the final products made from raw material. Clay minerals correspond to phyllosilicates, that is, hydrated aluminum, iron, and magnesium silicates with 
layered structures, including palygorskites and sepiolites (Díaz \& Torrecillas, 2002).

For this reason, one of the essential characteristics to be evaluated in clays is the chemical and mineralogical composition, since it directly influences the properties of the ceramics products. For example, clays with a high kaolinite content will allow obtaining ceramic products with refractory character, precise coloration, and excellent mechanical resistance. In contrast, high contents of illite and montmorillonite confer high plasticity to ceramic pastes, which translates into natural shaping of the pieces, but also in a significant contraction of them during drying and sintering, which can lead to the formation of cracks (Vieira, Sánchez, \& Monteiro, 2008); In such cases, degreasing material (sand) should be added to adjust the plasticity of the paste.

Therefore, plasticity is another critical parameter to control; this being understood as the property that clays have to form a plastic mass with water. One of the simplest methods to determine such property is that of the Atterberg limits (ASTM, 2005), which comprise the liquid limit (\% of the moisture that a soil possesses when it is in the limit between the liquid state and the plastic state), limit plastic (which corresponds to the lowest humidity at which a soil can be molded) and plasticity index, which is the difference between the two previous limits and indicates the clay's workability range.

The granulometric distribution is another variable since it will depend on the degree of packing of the particles and the physicalmechanical properties of the ceramics (porosity, water absorption, and flexural strength). On the other hand, the granulometric distribution allows predicting the plastic or degreasing character of the clay, taking into account that the clay material has small particle sizes of the order of a few microns. In contrast, the degreasing or sandy fraction has a particle size much older (Amado, Villafrades, \& Tuta, 2011) (R.A. García-León, Flórez-Solano, \& Acevedo-Peñaloza, 2018a)(Diaz Torrez, 2018).

\section{RESULTS AND DISCUSSIONS}

It is in this way that the granulometry of the selected samples was obtained as well as the chemical characterization by FRX and DRX. Screening granulometry is essential to define the particle size distribution, soil gradation, and to predict problems that could arise in the future (Ricardo Andrés García-León \& Bolívar, 2017). This analysis is complemented by hydrometric granulometry, which allows knowing the percentage of excellent material present in a soil sample, data that is not possible to determine using sieve granulometry, and that is essential to predict its behavior. When tabulating the data, the clay percentage of the soil sample is determined, the particles with a diameter smaller than $0.002 \mathrm{~mm}$. However, the percentages of sands, silts, and clays are defined in detail in Figure 3. The values of granulometry for the samples are calculated, taking into account that particles with values up to 100 millimeters correspond to gravels, between 100 and 0.08 millimeters correspond to sand, between 0.08 and 0.005 millimeters correspond to silt and particles with a diameter between 0.005 to 0 millimeters correspond to clay.

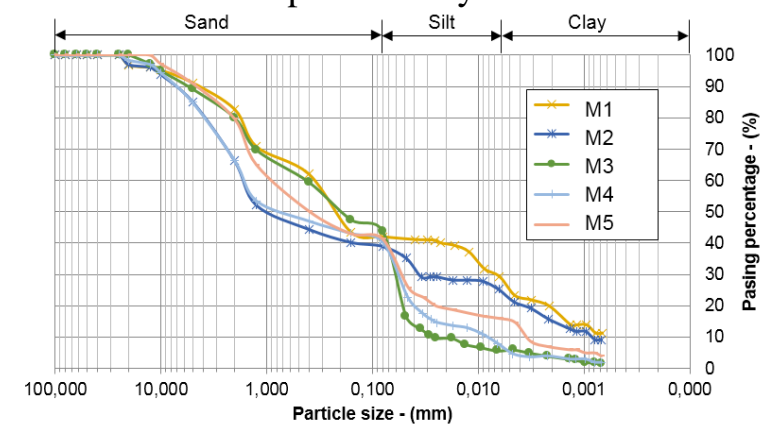

Figure 3. Soil classification based on the sieve and hydrometric graphs.

Source. Own elaboration

The percentages of sand, silt, and clay were summarized in Table 1.

Table 1. Hydrometric data by particle size.

\begin{tabular}{|c|c|c|c|}
\hline & \% & \% SILT & \% CLAY \\
SAMPLE & $\begin{array}{c}\mathbf{1 0 0 ~} \mathbf{~ m m} \\
-\mathbf{0 . 0 8} \\
\mathbf{~ m m}\end{array}$ & $\begin{array}{c}\mathbf{0 . 0 8} \mathbf{~ m m} \\
-\mathbf{0 . 0 0 5} \\
\mathbf{~ m m}\end{array}$ & $\begin{array}{c}\mathbf{0 . 0 0 5} \mathbf{~ m m}-\mathbf{0} \\
\mathbf{~ m m}\end{array}$ \\
& 58.0 & 18.0 & 24.0 \\
\hline M1 & 61.0 & 17.8 & 21,2 \\
\hline M2 & 56.3 & 38.1 & 5.9 \\
\hline M3 & &
\end{tabular}




\begin{tabular}{|c|c|c|c|}
\hline M4 & 59.7 & 31.1 & 4.6 \\
\hline M5 & 58.0 & 27.0 & 15.0 \\
\hline
\end{tabular}

Source. Own elaboration

For the estimation of the plasticity index of the soil, it is necessary to determine the liquid limit and the plastic limit of the samples and the plasticity index will be the difference between these two values. If it is a decimal, it approximates the nearest integer. In the case of being zero $(0)$ or less, the soil sample is assumed as "non-plastic".

All the samples are in the CL-ML zone, taking into account the Casagrande diagram when ML is inorganic silts and fine sands, clean silts, fine sands, silt, or clay with slight plasticity. CL is inorganic clays of plasticity low to medium, gravel clays, sandy clays, silty clays), which are considered as sand-clayey-silty samples with some or few low plasticity gravels. Therefore, the plasticity index (PI) shows that the samples are low plasticity clays (limes with clay traces between 4-15, according to the information obtained in the references). They are samples that are found in the Marnosas, Ferritics, red soil, and decalcification clays zone.

On the other hand, with the plasticity of the samples, it is possible to predict the extrusion behavior of the samples with these values, as shown in Figure 4.

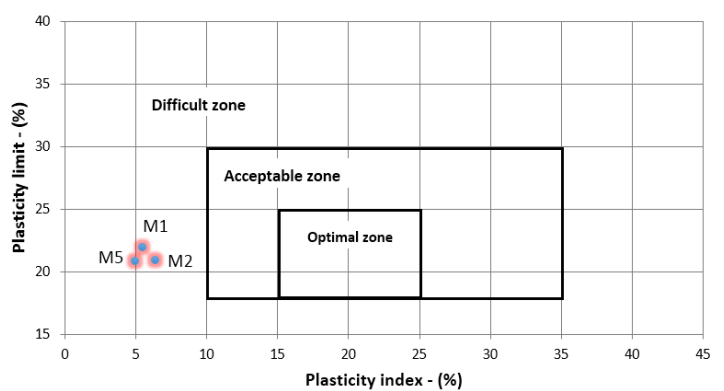

Figure 4. Diagram of prediction of extrusion and/or molding through the Atterberg Limits. Source. Own elaboration.

\subsection{Chemical and Mineralogical Characterization}

X-ray Fluorescence (FRX) is a non-destructive test, which analyzes an X-ray spectrum emitted by the sample, known as fluorescence (Roquet María, 2012) (Rozo Rincón, Sánchez Molina, \&
Gelves Díaz, 2015)(Perales López \& Barrera Vargas, 2013), this test also called ray spectrography $\mathrm{X}$, is a physical method for the analysis of clay materials, the main objective is to determine the qualitative and quantitative chemical composition of a sample. The importance of knowledge of the chemical composition and clay materials lies in principle as a complementary method in the identification of clay minerals. The results are shown in Table 2 for the sample M1 due to good behavior and soil classification.

Table 2. Result of the X-ray Fluorescence (FRX) analysis.

\begin{tabular}{|c|c|c|}
\hline NAME & ELEMENT & $\begin{array}{c}\text { RAW } \\
\text { MATERIAL } \\
\text { (M1) }\end{array}$ \\
\hline $\begin{array}{c}\text { Aluminum } \\
\text { Oxide }\end{array}$ & $\mathrm{Al}_{2} \mathrm{O}_{3}$ & 20.44 \\
\hline Calcium Oxide & $\mathrm{CaO}$ & 1.27 \\
\hline Iron Oxide & $\mathrm{Fe}_{2} \mathrm{O}_{3}$ & 6.70 \\
\hline $\begin{array}{c}\text { Potassium } \\
\text { Oxide }\end{array}$ & $\mathrm{K}_{2} \mathrm{O}$ & 3.29 \\
\hline $\begin{array}{c}\text { Magnesium } \\
\text { Oxide }\end{array}$ & $\mathrm{MgO}$ & 1.52 \\
\hline Sodium Oxide & $\mathrm{Na}_{2} \mathrm{O}$ & 0.81 \\
\hline Silice Oxide & $\mathrm{SiO}_{2}$ & 56.7 \\
\hline Sulfur trioxide & $\mathrm{SO}_{3}$ & 0.07 \\
\hline $\begin{array}{c}\text { Calcium } \\
\text { carbonate }\end{array}$ & $\mathrm{CaCO}_{3}$ & 5.19 \\
\hline Lost by Ignition & $\mathrm{LOI}$ & 4.01 \\
\hline
\end{tabular}

Source. Own elaboration

Fluorescence analyses showed the following characteristics for each chemical element:

- Silica $\left(\mathrm{SiO}_{2}\right)$ of $56.7 \%$ for the two mixtures, respectively, which causes a rapid drying process, in cooking a decrease in contraction; alumina was also found in high percentages for the two mixtures. Taking into account that chemical characteristics recommended for construction are 50 to $60 \%$.

- Alumina $\left(\mathrm{Al}_{2} \mathrm{O}_{3}\right)$ of $20.44 \%$ for the two mixtures, respectively, giving it a hightemperature resistance and a decrease in cooking breaks. Given that the chemical characteristic recommended for construction is 20 to $30 \%$.

- Montmorillonite clays because their chemical composition is: $\mathrm{SiO}_{2}: 48-56 \%, \mathrm{Al}_{2} \mathrm{O}_{3}: 11-22 \%$, MgO: $0.3-0.8 \%$.

- Iron oxide $\left(\mathrm{Fe}_{2} \mathrm{O}_{3}\right)$ of $6.70 \%$ for the sample is normal because they are less than $10 \%$. This oxide will give it a red color after burning. Due 
to its percentage, the black heart effect may not appear.

- The low contents of alkaline oxides (sodium and potassium) and alkaline earth oxides (magnesium and calcium), make it possible for the clay to generate the vitreous phase at relatively high temperatures (greater than 900 ${ }^{\circ} \mathrm{C}$ ), giving it semi-refractory properties.

The presence of high content of potassium oxide $\left(\mathrm{K}_{2} \mathrm{O}\right)$ of $3.29 \%$, above the other alkaline and alkaline earth oxides, classifies it as an illicit material, the other elements are in low proportions that will not affect the structure of the final product.

On the other hand, X-ray diffraction (XRD), allows the identification of crystalline and nonclayey crystalline phases. Because all crystalline solids have a characteristic diffractogram, their interpretation in both their qualitative and quantitative aspects can yield conclusions about their polymorphism, phase transitions, solid solutions, particle size measurement and determination of phase diagrams (Roquet María, 2012)(Środon, 2006)(Rozo Rincón, Sánchez Molina, \& Gelves Díaz, 2014)(Duitama, Espitia, Mojica, Quintero, \& Romero, 2004)(Zeballosvelásquez, Melero, Trujillo, Mejía, \& Ceroni, 2014). XRD test performs the structural characterizations and identifications of crystalline phases (Peña Rodríguez \& Ortega Triana, 2014), also essentially identifies the crystalline minerals present in a sample, since the clay minerals correspond to this type. Mostly clay mixtures have a composition for example: $50 \%$ kaolinite $+30 \%$ quartz $+20 \%$ potassium feldspar (Rendon Ríos, 2009).

Figure 5 shown the pattern of XRD of the minerals with clay-sized particles. Oriented, Glycolinated and calcined patterns, and expansive clay: montmorillonite, nontronite, or beidellite.

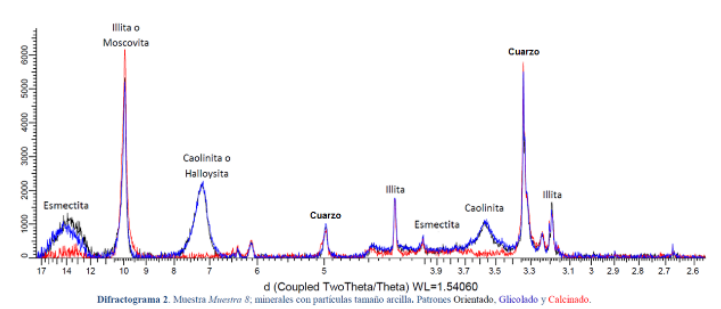

Figure 5. Result of the X-ray Diffraction analysis (XRD). Note: Minerals with clay-sized particles. Oriented, Glycolinated, and calcined patterns.

Source: Own elaboration

XRD pattern shows the presence of illite at positions (20) $10.2^{\circ} ; 5.19^{\circ} ; 3.68^{\circ}$ and $3.22^{\circ}$, Kaolin at positions $7.56^{\circ}$ and $3.58^{\circ}$, montmorillonite in the form of smectite is also observed at $14.15^{\circ}$. Likewise, in the diagrams between the 12 to $14^{\circ}$ position, smectite appears when the glycol analysis has been fully executed and has decreased after being calcined at $550{ }^{\circ} \mathrm{C}$ for two hours, which is evidenced at $7^{\circ}$ the presence of Kaolinic.

\section{CONCLUSIONS}

The samples had a similar behavior observing their curves in the hydrometry and sieving graphs. However, individualizing the tests, the one that behaved more regularly was sample M1, with $36 \%$ of sand, $32 \%$ of silt, and $32 \%$ of clay. However, the composition of these clays does not move far from the optimum range, furthermore said composition could be easily achieved by mixing such clays. The alumina content in the mixtures has a direct impact on the mechanical strength of the masonry product, as well as the presence in the mixtures of iron oxide content necessary for impermeability, durability, strength, and hardness.

The problem in the block manufacturing process is in the size of the sand particles, which are up to $2.0 \mathrm{~mm}$, so the crushing and rolling process is not effectively obtaining bad spraying, which makes that the final product possesses characteristics of high water absorption that weakens the compressive strength as evidenced in the technological tests.

According to the analysis of the data obtained in the tests of compression, water absorption and the position of the block in the baking oven, it was possible to show the variation between its properties with respect to the spatial geometric location in the oven chambers, taking into account that the highest temperature is concentrated in the upper part of the bedroom, generating better properties. In the upper and middle zone, the blocks develop better properties than in the lower zone because the blocks that are in the lower part support the weight of others, 
pointing this out as one of the possible causes of default losses.

The results of the granulometry tests indicate that the majority of the company's samples have an average index of $45 \%$ of fine sand taking into account the granulometric graph; the result of great importance for the manufacture of ceramic pastes, because it allows to classify the samples as materials of low compaction, low plasticity, which should not be used individually for production because they will have low resistance in dry and cooked, as well as high water absorption. Also, sand is necessary for extrusion because it helps reduce drying time and prevents the formation of cracks in pieces.

In general, the samples evaluated have high sand contents, greater than $25 \%$. Those of less than $10 \%$, average contents between 10 and $25 \%$, and high above $25 \%$ are considered low sand contents. The percentages of sand suitable for the manufacture of extruded ceramic products range between $16 \%$ and a maximum of $35 \%$. Also, the mixtures do not need the extra addition of sand to be able to extrude correctly.

\section{REFERENCES}

ASTM. (2005). Standard Test Methods for Liquid Limit, Plastic Limit, and Plasticity Index of Soils. ASTM International, 04(March 2010), 114. https://doi.org/10.1520/D4318-10.

Barranzuela, J. (2014). Proceso productivo de los ladrillos de arcilla producidos en la región piura. Universidad de Piura.

Cely-Illera, L. (2016). Raw materials for the ceramics industry from norte de santander. I. Mineralogical, chemical and physical characterization. Revista Facultad de Ingeniería Universidad de Antioquia, (80), 3137. https://doi.org/10.17533/udea.redin.n80a04

Díaz, L. A., \& Torrecillas, R. (2002). Arcillas cerámicas: Una revisión de sus distintos tipos, significados y aplicaciones. Boletin de La Sociedad Espanola de Ceramica Y Vidrio, 4l(5), 459-470.

Diaz Torrez, E. J. (2018). Diagnóstico del cumplimiento de la calidad de los bloques $\mathrm{H}-10$ fabricados por la ladrillera hora limitada en Ocaña Norte de Santander. Tesis de pregrado en Ingeniería Mecánica, Universidad Francisco de Paula Santander Ocaña.

Duitama, L., Espitia, C., Mojica, J., Quintero, J., \& Romero, F. (2004). Composición mineralógica y química de las arcillas empleadas para cerámica roja en las zonas de Medellín. Revista Academica Colombiana de Ciencia, 34(109), 555-564.

García, E., \& Suárez, M. (2004). Las Arcillas: Propiedades Y Usos.

García-León, R. A., Acevedo-Peñaloza, C., \& RojasSuarez, J. (2019). Metodologia para la fabricación del bloque H-10 para la industria cerámica del Norte de Santander. Bogota, Colombia: ECOE Ediciones.

García-León, R. A., Acosta, M. A., \& Flórez, E. (2015). Análisis del comportamiento de los frenos de disco de los vehículos a partir de la aceleración del proceso de corrosión. Tecnura, 19(45), 53-63. https://doi.org/10.14483/udistrital.jour.tecnura. 2015.3.a04

García-León, R. A., \& Bolívar, R. (2017). Caracterización Hidrométrica de las Arcillas Utilizadas en la Fabricación de Productos Cerámicos en Ocaña , Norte de Santander. INGE CUC, 13(1), 1-9. https://doi.org/http://dx.doi.org/10.17981/ingec uc.13.1.2017.05

García-León, R. A., Bolívar, R., \& Flórez, E. (2016). Validación de las propiedades físico-mecánicas de bloques H-10 fabricados en Ocaña Norte de Santander y la región. Ingenio UFPSO, 10(2011-642X), 17-26.

García-León, R. A., \& Flórez, E. (2016). Determinación de la ventana del proceso productivo en la fabricación de bloques $\mathrm{H}-10$ en Ocaña Norte de Santander y la región. Ingenio UFPSO, 09(2011-642X), 35-43.

García-León, R. A., Flórez-Solano, E., \& AcevedoPeñaloza, C. H. (2018). Physical-ceramic characterization of clays used in the manufacture of mansory products for construction. Respuestas, 23(2), 12-21.

García-León, R. A., Flórez-Solano, E. N., \& Acevedo-Peñaloza, C. H. (2018a). Caracterización Térmica de mezclas de arcillas utilziadas en la fabricación de productos de mampostería para la construcción. Revista Colombiana de Tecnologías de Avanzada, 1(31), 22-30.

García-León, R. A., Flórez-Solano, E. N., \& Acevedo-Peñaloza, C. H. (2018b). Clay surface characteristics using atomic force microscopy. Revista Facultad de Ingenieria, Universidad de Antioquia, 1(87), 23-34. https://doi.org/10.17533/udea.redin.n87a04

García-León, R. A., Flórez-Solano, E. N., \& MedinaCardenas, Y. (2018). Caracterización física de las arcillas utilizadas en la fabricación de 
productos de mampostería para la construcción en Ocaña Norte de Santander (Colombia). Revista Espacios, 39(1), 6.

García-León, R. A., Flórez-Solano, E., \& RodríguezCastilla, M. M. (2019). Application of the procedure of the iso 50001:2011 standard for energy planning in a company ceramic sector. DYNA (Colombia), (86(209)).

Gelves, J. F., \& Sánchez, J. (2009). Comportamiento de las arcillas del Área Metropolitana de Cúcuta sometidas a proceso de moldeo por extrusión., (2).

Jácome Manzano, S. A. (2012). Evaluación termodinámica del proceso de cocción y análisis de gases en hornos a cielo abierto y Hoffman en Ocaña (Universida). Ocaña: Repositorio ufpso.

JEG Plaza, MAR Nuñez, (2017) Formación en competencias específicas para la industria del software colombiano. Experiencias del uso del aprendizaje basado en proyectos. Revista Colombiana de Tecnologías de Avanzada, ISSN: 1692-7257

L Tangarife, M Sánchez, M Rojas (2017). Modelo de interventoría de tecnologías de información en el área de conocimiento de la gestión del alcance de PMBOK® y alineado con ISO 21500 y COBIT®. Revista Colombiana de Tecnologías de Avanzada, ISSN: 1692-7257.

Martínez, A., \& Aguilar, T. (2012). Impacto socioeconómico de la Minería en Colombia. Sector de Minería a Gran Escala, 50.

Montoya, G. P., \& Montoya, R. (2014). Caracterización del sector cerámico tradicional del valle de aburrá y los riesgos profesionales latentes en su proceso productivo., 34-42.

Muñoz, R. A., Muñoz, J. A., Mancilla, P., \& Rodríguez, J. E. (2007). Caracterización fisicoquímica de arcillas del municipio de Guapi- costa pacífica caucana (Colombiana). Química, 31, 537-544.

Peña Rodríguez, G., \& Ortega Triana, L. R. (2014). Caracterización morfológica y estructural de polvos de cenizas volantes. $i+D, 14(2), 14-19$.

Perales López, N. J. ;, \& Barrera Vargas, M. (2013). Análisis estructural por DRX de una arcilla natural Colombiana modificada por pilarización. Revista de Investigaciones Universidad Del Quindio, 24(001), 100-106.

Rendon Ríos, C. M. (2009). Uso de materias primas colombianas para el desarrollo de baldosa cerámicas con alto grado de gresificación. Universidad Nacional de Colombia sede Medellin.

O Suarez, C Vega, E Sánchez, A Pardo. (2018) Degradación anormal de p53 e inducción de apoptosis en la red P53-mdm2 usando la estrategia de control tipo pin. Revista Colombiana de Tecnologías de Avanzada, ISSN: 1692-7257.

Riojas Castillo, O., \& Rodríguez Montaña, N. E. (2004). Características de hornos para productos cerámicos del Parque Minero Industrial El Mochuelo, localidad 19 de Bogotá, D.C. Con-Ciencias.

Roquet María, B. (2012). Métodos analíticos en geoquímica (DRX-FRX) y Pegmatitas, 1-12.

Rozo Rincón, S. M., Sánchez Molina, J., \& Gelves Díaz, J. F. (2014). Evaluación de minerales alumino silicatos de Norte de Santander para fabricar piezas cerámicas de gran formato. Facultad de Ingeniería, 24(38), 53-61. Retrieved from http://www.scielo.org.co/scielo.php?script=sci _arttext\&pid=S0121-

$11292015000100005 \& \operatorname{lng}=$ en $\& n r m=$ iso \&tlng $=\mathrm{es}$

Rozo Rincón, S. M., Sánchez Molina, J., \& Gelves Díaz, J. F. (2015). Evaluación de minerales alumino silicatos de Norte de Santander para fabricar piezas cerámicas de gran formato Norte de Santander Alumino silicates Minerals ' Evaluation for the Big Scale Ceramic Pieces Manufacturing Avaliação de minerais aluminossilicato. Facultad de Ingeniería, 24, 53-61.

Środon, J. (2006). Identification and Quantitative Analysis of Clay Minerals. Developments in Clay Science, $1(\mathrm{C}), \quad 765-787$. https://doi.org/10.1016/S1572-4352(05)010287

Vieira, C. M. F., Sánchez, R., \& Monteiro, S. N. (2008). Characteristics of clays and properties of building ceramics in the state of Rio de Janeiro, Brazil. Construction and Building Materials, 22(5), 781-787. https://doi.org/10.1016/j.conbuildmat.2007.01. 006

Zeballos-velásquez, E. L., Melero, P. C., Trujillo, A. L., Mejía, M. E., \& Ceroni, M. (2014). Estudio estructural de arcillas de Chulucanas por difracción de rayos-X y método de Rietveld. Revista Materia, 19 N 2(1517-7076), 159-170.

Zuluaga Castrillón, D., Henao Arrieta, A. P., García Palacio, D. F., Rodríguez, J. E., Hoyos Machado, Á. M., López, M. E., \& Gómez Álvarez, C. (2016). Caracterización térmica, química y mineralógica de un tipo de arcilla roja propia de la región andina Colombiana, empleada para la producción de ladrillos para construcción. Revista Colombiana de Materiales, (9), 53-63. 